\title{
Indoor Climate in Jesuit Church of Holy Name of Jesus in Telc
}

\author{
Ondřej Hnilica'; Stefan Bichlmair ${ }^{2}$; Josef Plášek ${ }^{3 *}$ \\ 1) National Heritage Institute, Regional Branch in Telc, Czech Republic \\ 2) Fraunhofer Institute for Building Physics IBP, Holzkirchen Branch, Germany \\ 3) Brno University of Technology, Faculty of Civil Engineering, Czech Republic
}

\begin{abstract}
The Jesuit church of Holy Name of Jesus from year 1667 is integral part of main square of Telc with Baroque houses from $17^{\text {th }}$ century listed in UNESCO World Heritage Site since 1992. The natural indoor climate of Jesuit church is heated only in occupied pews during liturgical ceremony in winter season. The hygrothermal analysis of natural indoor climate in Jesuit church is performed by preventive conservation method of Target range and Historical climate in period from April 2017 to October 2018. The obtained result shows appropriate indoor climate for preventive conservation of historical furniture (main altar, lateral chapels, pulpit, confessional, organ, paintings), holy remains and valuable artefacts for liturgical ceremony. This hygrothermal analysis of natural indoor climate in Jesuit church supports current state of local heating in occupied pews during liturgical ceremony in winter season.
\end{abstract}

\section{Introduction}

The historical church is usually monumental building with altar, chapel, pulpit, confessional, organ, paintings and other furniture. The sacral aspect of historical church is supported by holy remain and valuable artefacts for liturgical ceremony. The conservation of historical furniture, holy remain and valuable artefacts is important as spiritual and cultural heritage.

The conservation is possible to base on appropriate indoor climate with for delay of degradation process. This conservation method known as Target range is defined by hygrothermal range of appropriate indoor climate, see [1-8]. This method of Target range is useful in building with controlled indoor climate, for example museum, library, gallery, exhibition, see [6-8]. This conservation method of Target range is difficult to applied in case of natural indoor climate formed by outdoor weather.

The other preventive conservation approach is based on natural hygrothermal response of historical building. This conservation approach known as Historical climate method is based on long-term hygrothermal moving average and short-term fluctuation of indoor climate in past-present-future, see [9]. This conservation method of Historical climate is useful in historical building with natural indoor climate, see [10-12].

\subsection{Research Aim}

This conference contribution is aimed at hygrothermal analysis of experimental measurement of indoor climate in Jesuit church of Holy Name of Jesus in Telc, Czech Republic. This hygrothermal analysis of indoor climate is performed by preventive conservation method of Target range and Historical climate with respect to historical furniture (altar, chapels, pulpit, confessional, organ, paintings), holy remains and valuable artefacts for liturgical ceremony in Jesuit church from year 1667.

\section{Jesuit church of Holy Name of Jesus}

This Jesuit church of Holy Name Jesus is integral part of main square in town Telc with mainly Baroque houses from $17^{\text {th }}$ century listed in UNESCO World Heritage Site since 1992, see Fig. 1.

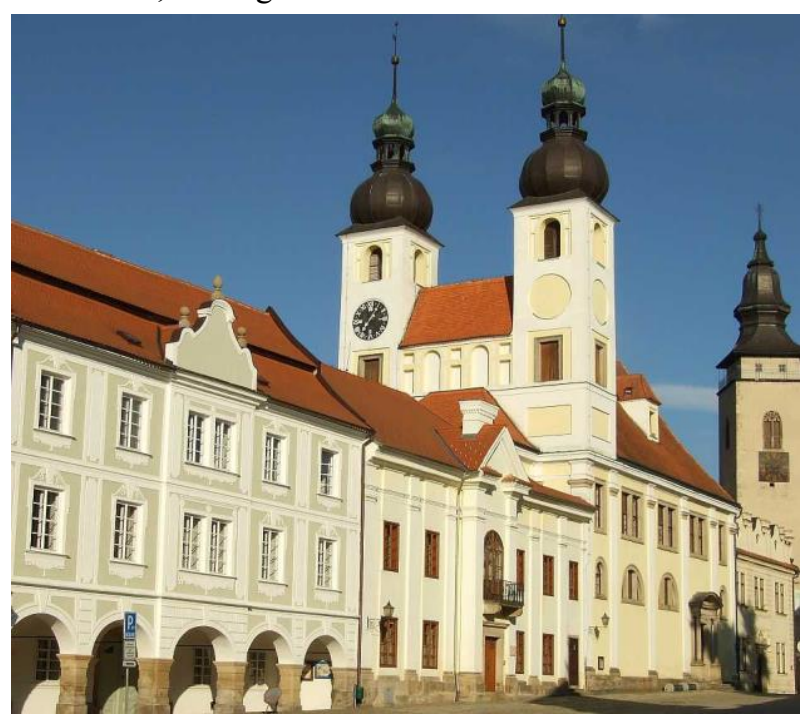

Fig. 1. Jesuit church of Holy Name Jesus in Telc.

\subsection{Historical context}

The Pope Paulus III during pontificate $(1534-1549)$ approved Society of Jesus (1540) with permission (1549) to build Jesuit churches at missionary region. This idea of new Jesuit church (from year 1662) is supported by good relation between Society of Jesus in Telc and donor 
of countess Frantiska Slavatova von Meggau (*1609 $\uparrow 1676$ ), source [13].

The first conception of Jesuit church in Telc is inspirited by Signum Crucis. This cross shape of Jesuit church is abandoned for difficult integration to urban design of main square in Telc, see [14], The second conception is designed in T-shape with two church towers oriented to main square. This conception is abandoned and other two conceptions are deposited in Moravian Archive in Brno [15] and Austrian National Library in Vienna [16]. These two conceptions show evolution of new Jesuit church in shape and orientation.

The architect of Jesuit church in Telc is not clear and researches by historiography are mentioned architect Carlo Lurago (IT, d'Intelvi *1615 - †1684 GE, Passau) and architect Giovanni Domenico Orsi (AT, Vienna *1634 - †1679 CZ, Prague). These architects were worked for Society of Jesus on other buildings, but direct historical source in case of Jesuit Church in Telc is not found. This connection is based on analysis of arthistorical form and architecture analogy. Moreover, architect G. D. Orsi during construction of Jesuit Church in Telc was assistant of architect C. Lurago. The builder of Jesuit church in Telc is Stephano Perti and his name is mentioned in annual report of Jesuit college in Telc in year 1676. This Jesuit church in Telc is built in total price 17255 guldens in years 1663 - 1667 and this total price is paid by countess Frantiska Slavatova. This price includes wood, quarry stone, hydrated lime, ceramics bricks in count 42800 pieces, horses for transport, salary for workers, and beer for workers from two breweries in price 2146 guldens, source [17].

\subsection{Construction of Jesuit Church}

The Jesuit church in Telc from year 1667 is located uncommonly with two towers in row of Baroque houses and therefore main entrance is located uncommonly also at left side of church, see Fig. 1. The entrance portal to Jesuit church in Telc is inspired by church Santo Stefano in Castiglione d'Intelvi in the North Italy [18], see Fig. 2.
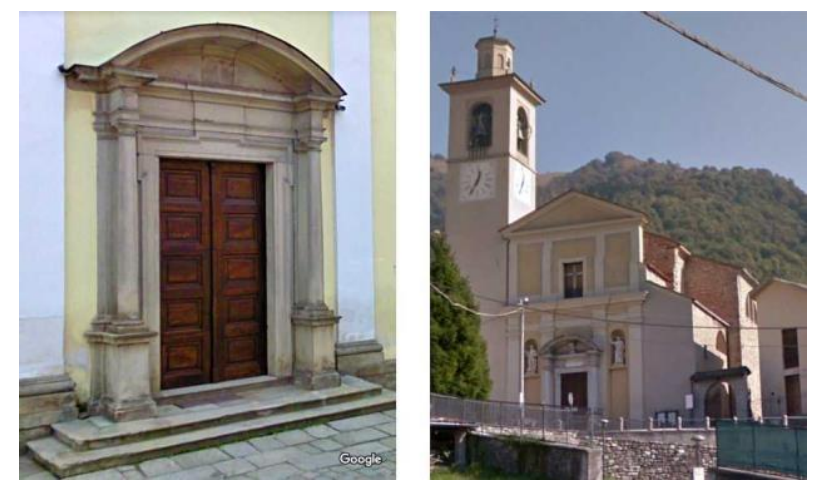

Fig. 2. Portal of main entrance to Jesuit church in Telc (left) [19] and church Santo Stefano in Castiglione d'Intelvi in Italy near to lake Como (right) [20], see birthplace of C. Lurago.

This Jesuit church in Telc type of wandpfeilerkirche includes central nave with lateral chapels between wall pillars on both sides. The main altar in presbytery is flanked by two church towers. The left church tower on Evangelist side is used for spiral staircase to gallery above lateral chapels. The right church tower on Epistle side includes corridor to sacristy. This sacristy is located in neighbour Jesuit college. The under-roof space of Jesuit church is accessible also from Jesuit college. The historical timber roof is type of lying chair in early Baroque style. Under the Jesuit church is located large crypt accessible from courtyard of Jesuit college in Telc. This crypt is connected with two closed tunnels below square in Telc, see Fig. 3.

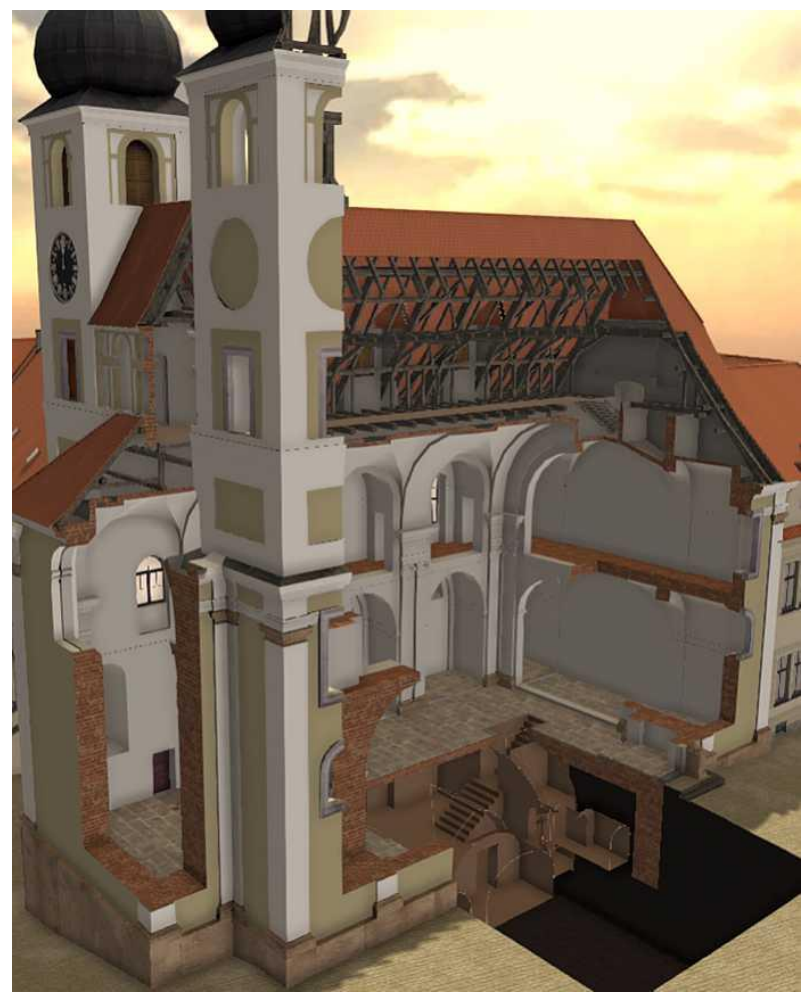

Fig. 3. Visual 3D model of Jesuit church in Telc [21].

\subsection{Internal disposition of Jesuit Church}

The internal disposition of Jesuit church is designed with accordance to Concilium Tridentinum (1545 - 1563) launched by Pope Paulus III. The simple interior of Jesuit church is painted by white colour and decorated by historical furniture. This interior includes six lateral chapels between wall pillars on both sides and main altar in presbytery, see Fig. 4.

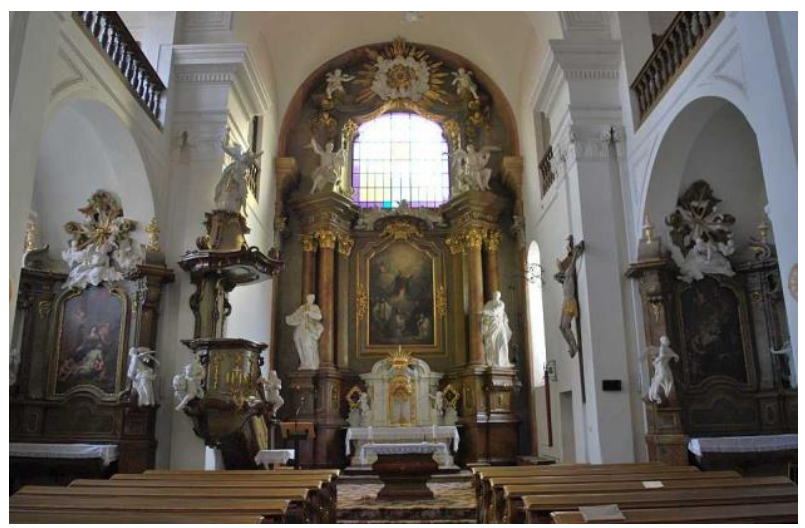

Fig. 4. The main altar and pulpit in presbytery with two lateral chapels on sides in Jesuit church of Holy Name Jesus in Telc. 
The choir loft with organ is located in central nave opposite to presbytery, see Fig. 5. The indoor climate in Jesuit church in Telc is possible to heat by radiant panels located in 12 rows of wooden pews. The heat power of one radiant heat panels is $125 \mathrm{~W}$ and count of installed radiant heat panel is 48 pieces. The maximal installed heat power is $6 \mathrm{~kW}$. The local radiant heating in wooden pews for visitors is used only during liturgical ceremony in occupied pews (usually lower than 3 rows) in winter season, see Fig. 6.

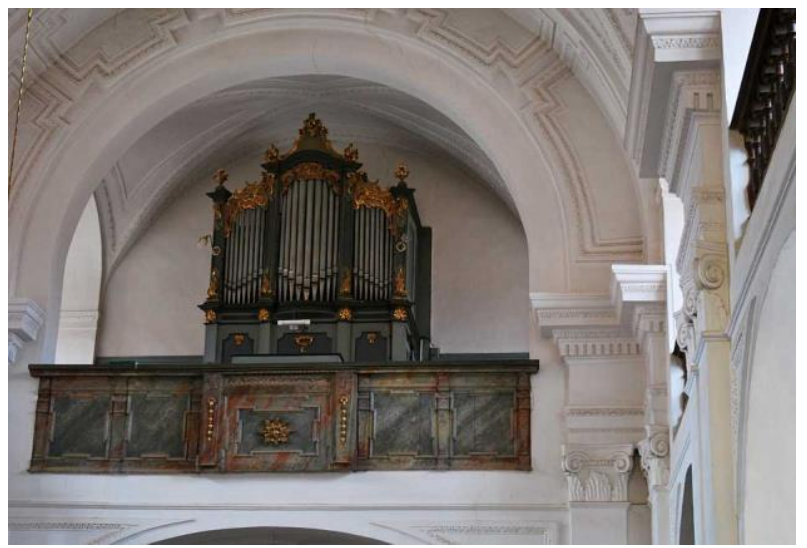

Fig. 5. Gallery with organ opposite to presbytery in Jesuit church in Telc.

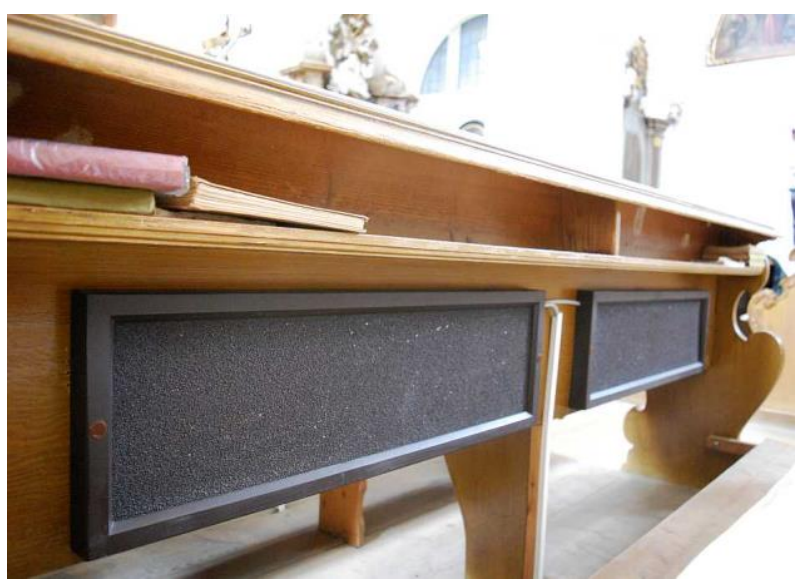

Fig. 6. Radiant heat panel in pew of Jesuit church in Telc.

\section{Results}

The hygrothermal measurement of indoor climate in Jesuit church in Telc is performed on right side of presbytery in height $3.20 \mathrm{~m}$ above floor. The outdoor climate in Telc is measured at north-east façade of Jesuit church in height $11.20 \mathrm{~m}$ above ground. The outdoor and indoor hygrothermal sensor is data logger Comet S3120 with temperature range from $-30{ }^{\circ} \mathrm{C}$ to $70{ }^{\circ} \mathrm{C}$, sensitivity $\pm 0.10 \mathrm{~K}$ and accuracy $\pm 0.40 \mathrm{~K}$. The range of data logger Comet S3120 for air relative humidity is from $5 \%$ to $95 \%$ with sensitivity $\pm 0.10 \% \mathrm{RH}$ and accuracy $\pm 2.5 \% \mathrm{RH}$. These hygrothermal sensors of outdoor and indoor climate are measured in period from $27^{\text {th }}$ April $2017(12: 20 \mathrm{am})$ to $23^{\text {rd }}$ October $2018(11: 00 \mathrm{am})$ with interval of record 20 minutes. This hygrothermal measurement includes record of outdoor/indoor air temperature, outdoor/indoor air relative humidity and outdoor/indoor dew-point temperature.

\subsection{Analysis of Indoor and Outdoor Climate}

The continual hygrothermal measurement over 543 days is plotted by red line for indoor air temperature, blue line for indoor air relative humidity, purple line for indoor dew-point temperature and grey line for outdoor climate, see Fig. 7. This graph includes also coloured area named as Frost risk $\left(\mathrm{T}<0{ }^{\circ} \mathrm{C}\right)$, Microbiology risk $(\mathrm{RH}>80 \%)$ and Dryness effect $(\mathrm{RH}<40 \%)$ according to [22].

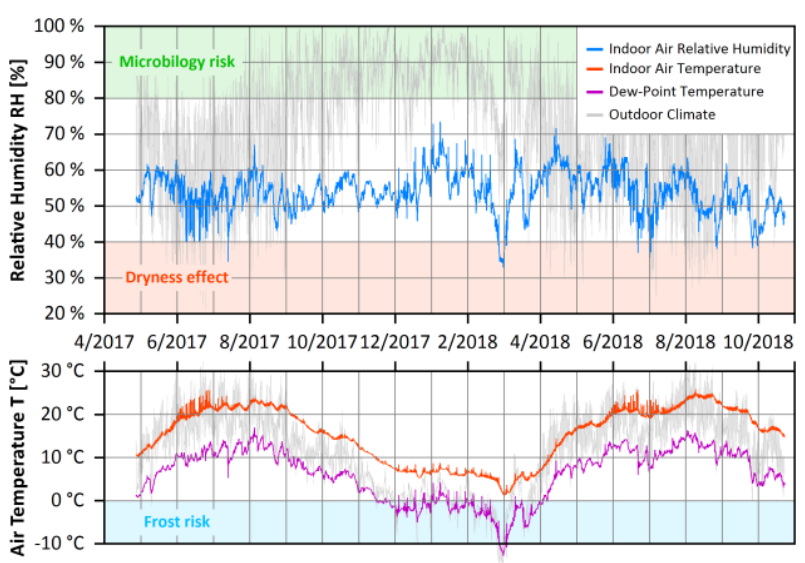

Fig. 7. Hygrothermal measurement of outdoor and indoor climate in period from $27^{\text {th }}$ April 2017 to $23^{\text {rd }}$ October 2018.

The median of indoor air temperature is $16.7{ }^{\circ} \mathrm{C}$ with minimal indoor air temperature $1.10^{\circ} \mathrm{C}\left(2^{\text {nd }}\right.$ March 2018 at 4:40 am) and maximal indoor air temperature $25.9^{\circ} \mathrm{C}$ ( $9^{\text {th }}$ August 2018 at 18:00 pm). The minimal indoor air temperature is caused by unusually frozen days in period from $25^{\text {th }}$ February 2018 to $1^{\text {st }}$ March 2018 with outdoor air temperature in range from $-15.8{ }^{\circ} \mathrm{C}$ to $-6.9{ }^{\circ} \mathrm{C}$. The average outdoor air temperature over 5 days is $-11.5^{\circ} \mathrm{C}$. The indoor air temperature shows regular fluctuation in June at time about 7:20 am. This fluctuation of indoor air temperature is caused by direct solar radiation over window in presbytery on wall with indoor sensor.

The median of indoor air relative humidity is $54.4 \%$ with minimal indoor air relative humidity $32.9 \%$ ( $1^{\text {st }}$ March 2018 at 12:40 pm). This minimal indoor air relative humidity is coupled with end of unusually frozen days. The indoor air relative humidity over frozen days is measured in risked area Dryness effect $(\mathrm{RH}<40 \%)$ for 127 hours with insignificant frequency $9.6 \%$ from 543 measured days. The Dryness effect in summer season is caused by direct solar radiation over window in presbytery on wall with indoor sensor. The maximal indoor air relative humidity is $73.5 \%\left(7^{\text {th }}\right.$ January 2018 at 11:00 am) and this maximal indoor air relative humidity is measured at Sunday with liturgical ceremony of Three Kings.

The median of indoor dew-point temperature is $7.4{ }^{\circ} \mathrm{C}$ with minimal indoor dew-point temperature $-12.8{ }^{\circ} \mathrm{C}$ ( $1^{\text {st }}$ March 2018 at 12:40 pm) and maximal dew-point temperature $17.0{ }^{\circ} \mathrm{C}$ ( $4^{\text {th }}$ August 2017 at $18: 40 \mathrm{pm}$ ). The minimal indoor dew-point temperature is coupled with end of frozen days. The maximal indoor dew-point temperature and maximal indoor air temperature shows start of August as period with highest indoor dew-point temperature. 


\subsection{Hygrothermal Time-lag of Indoor Climate}

The natural indoor climate in Jesuit church in Telc is significantly influenced by outdoor climate. This outdoor climate in Telc includes hot summer season $\left(32.9{ }^{\circ} \mathrm{C}\right.$ in time $16: 20 \mathrm{pm}$ at $1^{\text {st }}$ August 2017) and cold winter season $\left(-15.8{ }^{\circ} \mathrm{C}\right.$ in time 8:00 am at $26^{\text {th }}$ February 2018). The hygrothermal time-lag between outdoor and indoor climate is possible to calculate with use of Fourier transform method. This Fourier transform method is based on time-shift of two waves. The stable wave is hygrothermal record of outdoor climate and shifted wave is hygrothermal record of indoor climate. The time step of wave shift is interval of data record (20 minutes). The difference between waves over 39164 hygrothermal records is evaluated by Correlation coefficient and Root Mean Square method.

The result of calculation shows time-lag of indoor air temperature on 95 hours (almost 4 day) with correlation coefficient over $89 \%$ and temperature attenuation $5.5{ }^{\circ} \mathrm{C}$ in envelope of historical church. The time-lag of indoor air relative humidity is obtained on value lower than interval of record (20 minutes). The time-lag of dewpoint temperature is calculated on 320 minutes (about 5 hours) with correlation coefficient over $94 \%$ and hygrothermal attenuation $2.4{ }^{\circ} \mathrm{C}$ in envelope of historical church.

\subsection{Hygrothermal difference of Indoor climate}

The natural indoor climate in Jesuit church is measured over 543 days in interval 20 minutes. This evolution of natural indoor climate in time is discretized in 39164 hygrothermal time steps. The hygrothermal difference of indoor climate is possible to plot in point graph as temperature difference on vertical axis and difference of indoor air relative humidity on horizontal axis. The point in graph is coloured according to month in the year. The winter season is coloured by blue shades and summer season is coloured by red shades, see Fig. 8 .

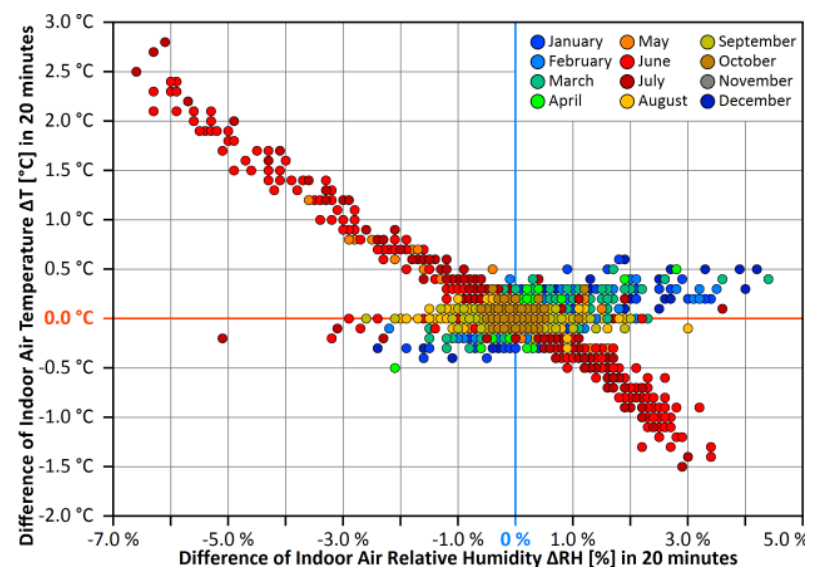

Fig. 8. Hygrothermal difference of indoor climate measured in period from $27^{\text {th }}$ April 2017 to $23^{\text {rd }}$ October 2018.

This hygrothermal analysis of indoor climate in Jesuit church shows difference of indoor air temperature in range from $-1.50{ }^{\circ} \mathrm{C}\left(2^{\text {nd }}\right.$ June 2018 at $8: 00$ am) to $2.8^{\circ} \mathrm{C}$ ( $2^{\text {nd }}$ June 2018 at 7:40 am). These differences of indoor air temperature in summer season (red points) are caused by direct solar radiation over window in presbytery on wall with indoor sensor.

The difference of indoor air relative humidity in Jesuit church is measured in range from $-6.6 \%\left(7^{\text {th }}\right.$ July 2018 at 7:40 am $)$ to $4.4 \%\left(10^{\text {th }}\right.$ December 2017 at $\left.18: 20 \mathrm{pm}\right)$. The difference of indoor air relative humidity in winter season (three blue points near to $4.0 \% \mathrm{RH}$ and $0.5 \mathrm{~K}$ ) is measured at time 18:20 am in each Advent Sunday $3^{\text {rd }}$, $10^{\text {th }}, 17^{\text {th }}$ December 2017 . This hygrothermal difference of indoor climate is caused by moisture production of persons during liturgical ceremony in Jesuit church.

The hygrothermal difference of indoor climate in Jesuit church in summer season (red points) is higher than hygrothermal difference in winter season (blue points), see Fig. 8. The optical orthogonal raster of points in graph is caused by hygrothermal sensitivity of sensor for air temperature $\pm 0.10 \mathrm{~K}$ (optical rows) and relative humidity $\pm 0.10 \%$ (optical columns).

\subsection{Target range method}

The hygrothermal measurement of indoor climate in Jesuit church is possible to display in point graph with indoor air temperature on horizontal axis and indoor air relative humidity on vertical axis in interval 20 minutes. The point in graph is coloured according to month in the year. The winter season is coloured by blue shades and summer season is coloured by red shades, see Fig. 9.

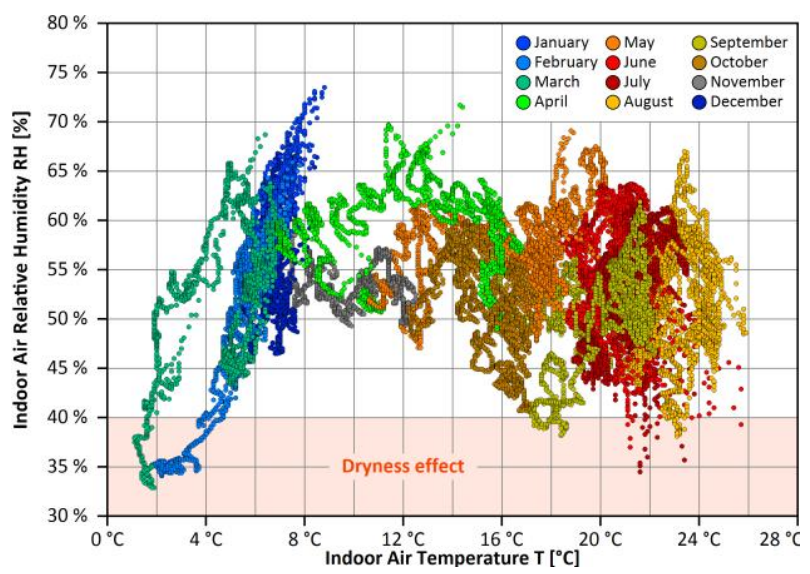

Fig. 9. Hygrothermal measurement of indoor climate in period from $27^{\text {th }}$ April 2017 to $23^{\text {rd }}$ October 2018.

The preventive conservation method of Target range is based on appropriate indoor climate. This appropriate indoor climate is leaded by air temperature and relative humidity. This hygrothermal range of indoor climate is defined by many standards and recommendations. The researcher D'Agostino in $\mathrm{PhD}$ Thesis [2] summarized chosen Target range of indoor climate from M.BB.CC. 2001 [3]; Italian Standard UNI 1999 [4]; U.K. Institute for conservation [5]; Musée de France [6]; Museo a Roma [7]; Baumont-Laurie [1] and Thomson [8], see Table 1.

This appropriate indoor climate in Target range depends on material and surface of historical furniture and valuable artefact. The historical furniture (altar, lateral chapels, pulpit, confessional, organ, paintings), holy 
remains and valuable artefacts for liturgical ceremony in Jesuit church in Telc are sorted to seven categories according to material.

A) Bone relics in religion connects spiritual and secular world. The bone relic is insert in relic stone and located in altar.

B) Wood parts is wooden structure of main altar, wooden part of lateral chapels, wooden pulpit, wooden construction of organ, wooden doors and frame of painting.

C) Polychrome wood is part of main altar, pulpit, lateral chapels, organ, wooden parts of statues. The hygrothermal stress in polychrome wood increases risk of crackle and peeling.

D) Oil painting on canvas in main altar, canvas in lateral chapels, canvas in paintings on wall.

E) Bellows organ is built-in the organ. The organ is currently rebuilt on electric drive and bellows organ are still used during liturgical ceremony.

F) Light metals are used as locksmith ware and fittings on doors, altar, sanctuary and parts of liturgical artefacts for ceremony.

G) Wood inlays with lacquer is surface finish of altar, six chapels, pulpit, confessional, organ and frame of painting.

The frequency of natural indoor climate in Target range in period from $27^{\text {th }}$ April 2017 to $23^{\text {rd }}$ October 2018 is obtained in range from $3.90 \%$ measured days (see category B, E, F and G) to $68.8 \%$ days (see category A), see Table 1. The frequency of indoor climate in Target range in upper part of Table 1 is over $30 \%$ measured days (see category A - E). The end part of Table 1 shows frequency of indoor climate in Target range below $22 \%$ measured days (see category F and G). This low frequency of natural indoor climate in Target range is caused by temperature range more often than range of indoor air relative humidity, see Table 1. For example, category A - E shows appropriate indoor air relative humidity in frequency over $82 \%$ measured days, according to Italian Standard M.BB.CC., 2001 [3] and UNI 1999 [4], see frequency in brackets in Table 1.

The recommended minimal air temperature in Target range is often over $10{ }^{\circ} \mathrm{C}$, but natural indoor climate in Jesuit church formed by hygrothermal response of church is measured below $10^{\circ} \mathrm{C}$ in frequency $27 \%$ days.

This result shows on heating demand in Jesuit church, but heating of indoor climate is coupled with possible hygrothermal stress in historical furniture and valuable artefacts, see [23-25] The repetitive switch on/off of heating system causes cyclic drop of indoor air relative humidity as well as accelerate dust particles and deposit them on painting canvas etc., see [26-30]. The heating system is appropriate in case of indoor air temperature below $0{ }^{\circ} \mathrm{C}$, but frequency of Frost risk in Jesuit church in Telc is not detected.
Table 1. Frequency of Indoor climate in Target range.

\begin{tabular}{|c|c|c|c|}
\hline Information Source & $\boldsymbol{T}\left[{ }^{\circ} \mathbf{C}\right]$ & $\boldsymbol{R H}[\%]$ & Frequency \\
\hline \multicolumn{4}{|l|}{ A) BONE RELICS } \\
\hline $\begin{array}{l}\text { U.K. Institute for } \\
\text { conservation }\end{array}$ & $\begin{array}{l}10-25 \\
(73 \%)\end{array}$ & $\begin{array}{l}45-65 \\
(93 \%)\end{array}$ & $68.8 \%$ \\
\hline M.BB.CC., 2001 & $\begin{array}{l}19-24 \\
(38 \%)\end{array}$ & $\begin{array}{r}45-65 \\
(93 \%)\end{array}$ & $35.7 \%$ \\
\hline UNI 1999 & $\begin{array}{l}19-24 \\
(38 \%)\end{array}$ & $\begin{array}{c}40-60 \\
(86 \%)\end{array}$ & $34.2 \%$ \\
\hline
\end{tabular}

B) WOOD PARTS

\begin{tabular}{|c|c|c|c|}
\hline Thomson & $\begin{array}{c}15-25 \\
(60 \%)\end{array}$ & $\begin{array}{c}50-60 \\
(68 \%)\end{array}$ & $40.7 \%$ \\
\hline M.BB.CC., 2001 & $\begin{array}{c}19-24 \\
(38 \%)\end{array}$ & $\begin{array}{c}40-65 \\
(97 \%)\end{array}$ & $37.2 \%$ \\
\hline UNI 1999 & $\begin{array}{l}19-24 \\
(38 \%)\end{array}$ & $\begin{array}{c}45-60 \\
(82 \%)\end{array}$ & $32.7 \%$ \\
\hline Baumont-Laurie & $\begin{array}{l}19-24 \\
(38 \%)\end{array}$ & $\begin{array}{c}45-55 \\
(50 \%)\end{array}$ & $21.2 \%$ \\
\hline Museo a Roma & $\begin{array}{c}21-23 \\
(20 \%)\end{array}$ & $\begin{array}{c}35-50 \\
(19 \%)\end{array}$ & $3.90 \%$ \\
\hline
\end{tabular}

C) POLYCHROME WOOD

\begin{tabular}{|c|c|c|c|}
\hline M.BB.CC., 2001 & $\begin{array}{l}19-24 \\
(38 \%)\end{array}$ & $\begin{array}{l}45-65 \\
(93 \%)\end{array}$ & $35.7 \%$ \\
\hline UNI 1999 & $\begin{array}{l}19-24 \\
(38 \%)\end{array}$ & $\begin{array}{l}50-60 \\
(68 \%)\end{array}$ & $25.6 \%$ \\
\hline Baumont-Laurie & $\begin{array}{c}19-24 \\
(38 \%)\end{array}$ & $\begin{array}{l}35-55 \\
(55 \%)\end{array}$ & $22.8 \%$ \\
\hline Museo a Roma & $\begin{array}{l}21-23 \\
(20 \%)\end{array}$ & $\begin{array}{l}35-55 \\
(55 \%)\end{array}$ & $12.1 \%$ \\
\hline \multicolumn{4}{|c|}{ D) OIL PAINTINGS } \\
\hline M.BB.CC., 2001 & $\begin{array}{l}19-24 \\
(38 \%)\end{array}$ & $\begin{array}{l}35-60 \\
(87 \%)\end{array}$ & $34.3 \%$ \\
\hline UNI 1999 & $\begin{array}{l}19-24 \\
(38 \%)\end{array}$ & $\begin{array}{l}40-55 \\
(54 \%)\end{array}$ & $22.7 \%$ \\
\hline Baumont-Laurie & $\begin{array}{l}19-24 \\
(38 \%)\end{array}$ & $\begin{array}{l}35-50 \\
(19 \%)\end{array}$ & $9.00 \%$ \\
\hline
\end{tabular}

E) BELLOWS ORGAN

\begin{tabular}{|c|c|c|c|}
\hline UNI 1999 & $\begin{array}{c}19-24 \\
(38 \%)\end{array}$ & $\begin{array}{c}45-60 \\
(82 \%)\end{array}$ & $32.7 \%$ \\
\hline Baumont-Laurie & $\begin{array}{c}19-24 \\
(38 \%)\end{array}$ & $\begin{array}{c}35-50 \\
(19 \%)\end{array}$ & $9.00 \%$ \\
\hline Musée de France & $\begin{array}{c}18-20 \\
(9.4 \%)\end{array}$ & $\begin{array}{c}45-55 \\
(50 \%)\end{array}$ & $5.50 \%$ \\
\hline Museo a Roma & $\begin{array}{c}21-23 \\
(20 \%)\end{array}$ & $\begin{array}{c}35-50 \\
(19 \%)\end{array}$ & $3.90 \%$ \\
\hline
\end{tabular}

F) LIGHT METALS

\begin{tabular}{|c|c|c|c|}
\hline $\begin{array}{c}\text { U.K. Institute for } \\
\text { conservation }\end{array}$ & $\begin{array}{c}15-25 \\
(60 \%)\end{array}$ & $\begin{array}{c}50-55 \\
(36 \%)\end{array}$ & $22.0 \%$ \\
\hline UNI 1999 & --- & $\begin{array}{c}\leq 50 \\
(20 \%)\end{array}$ & $19.7 \%$ \\
\hline Museo a Roma & $\begin{array}{c}21-23 \\
(20 \%)\end{array}$ & $\begin{array}{c}25-50 \\
(20 \%)\end{array}$ & $3.90 \%$ \\
\hline
\end{tabular}

G) WOOD INLAYS WITH LACQUER

\begin{tabular}{|c|c|c|c|}
\hline Baumont-Laurie & $\begin{array}{c}19-24 \\
(38 \%)\end{array}$ & $\begin{array}{c}45-55 \\
(50 \%)\end{array}$ & $21.2 \%$ \\
\hline M.BB.CC., 2001 & $\begin{array}{c}19-24 \\
(38 \%)\end{array}$ & $\begin{array}{c}50-60 \\
(68 \%)\end{array}$ & $14.0 \%$ \\
\hline Museo a Roma & $\begin{array}{c}21-23 \\
(20 \%)\end{array}$ & $\begin{array}{c}35-50 \\
(19 \%)\end{array}$ & $3.90 \%$ \\
\hline
\end{tabular}




\subsection{Historical climate method}

The conservation method of Historical climate is based on natural hygrothermal response of historical building, see [9]. The historical furniture (altar, lateral chapels, pulpit, confessional, organ, paintings), holy remains and valuable artefacts for liturgical ceremony are adapted on natural indoor climate in Jesuit church since 1667.

The hygrothermal change of natural indoor climate in Jesuit church is coupled with reversible or irreversible internal tensions in material, see [30]. This internal tension increases risk of cracks, expansion, deformation, relaxation of joints etc. The method of Historical climate is applied as long-term hygrothermal moving average (over 30 days) and short-term fluctuation of indoor climate in range from $7^{\text {th }}$ to $93^{\text {rd }}$ percentile of measured values, see Fig. 10.

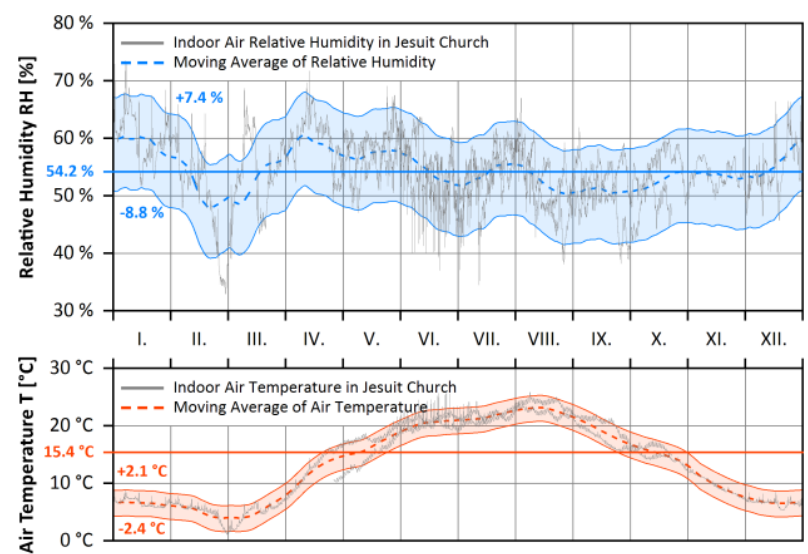

Fig. 10. Hygrothermal analysis of indoor climate by preventive conservation method of Historical climate in period from $27^{\text {th }}$ April 2017 to $23^{\text {rd }}$ October 2018.

The annual average of indoor air temperature in Jesuit church in Telc is $15.4{ }^{\circ} \mathrm{C}$. The moving average of indoor air temperature is obtained in range from $3.98{ }^{\circ} \mathrm{C}$ (28 $8^{\text {th }}$ February) to $23.2^{\circ} \mathrm{C}$ ( $14^{\text {th }}$ August $)$ with short-term fluctuation of indoor temperature in range from $-2.4{ }^{\circ} \mathrm{C}$ to $2.1{ }^{\circ} \mathrm{C}$. The annual average of indoor air relative humidity in Jesuit church is $54.2 \%$. The moving average of indoor air relative humidity is obtained in range from $47.9 \%\left(21^{\text {st }}\right.$ February $)$ to $60.7 \%\left(12^{\text {th }}\right.$ April $)$ with shortterm fluctuation of indoor air relative humidity in range from $-8.8 \%$ to $7.4 \%$. This short-term fluctuation of indoor climate lower than $\pm 10 \% \mathrm{RH}$ is assessment as stable indoor climate with lower risk of failures according to EN 15757, see [9].

\section{Discussion}

The outdoor and indoor climate in Jesuit church in Telc is measurement by hygrothermal data loggers located in presbytery and north-east façade in period from April 2017 to October 2018. This measurement over 543 days shows insignificant frequency of Microbiology risk, Frost risk and Dryness effect in Jesuit church, see 3.1.

This hygrothermal measurement is used for calculation of time-lag between outdoor and indoor climate ( 5 hours for dew-point temperature and 4 days for indoor air temperature). The hygrothermal attenuation in envelope of church $\left(2.4{ }^{\circ} \mathrm{C}\right.$ for dew-point temperature and $5.5{ }^{\circ} \mathrm{C}$ for indoor air temperature), see 3.2.

The hygrothermal difference of natural indoor climate in interval 20 minutes shows impact of solar radiation $\left(2.8^{\circ} \mathrm{C}\right)$ in summer season and impact of liturgical ceremony on indoor air relative humidity $(4.4 \% \mathrm{RH})$ at Advent Sundays, see 3.3.

The conservation method of Target range shows low frequency of natural indoor climate in recommended hygrothermal range, according to [1-8]. The appropriate indoor climate is obtained in range from $3.90 \%$ days (wood parts, bellows organ, light metals and wood inlays with lacquer) to $68.8 \%$ measured days (bone relics). This low frequency of indoor climate in Target range is caused by natural indoor air temperature, see 3.4.

The conservation method of Historical climate shows indoor climate in narrow hygrothermal corridor with short-term fluctuation of air temperature $<-2.4{ }^{\circ} \mathrm{C}$; $2.1^{\circ} \mathrm{C}>$ and short-term fluctuation of indoor air relative humidity $<-8.8 \% ; 7.4 \%>$. This short-term fluctuation shows stable indoor climate in Jesuit church, see 3.5.

This hygrothermal analysis shows appropriate indoor climate in Jesuit church for preventive conservation of historical furniture (main altar, lateral chapels, pulpit, confessional, organ, paintings), holy remains and valuable artefacts. This historical furniture and valuable artefacts are without failures, according to conservators. Therefore, idea from year 1993 about central heating system in Jesuit church is not supported. The current state of local radiant heating in occupied pews during liturgical ceremony is appropriate, because impact of local pews heating on historical furniture and valuable artefacts is insignificant. The other research is suitable aimed at organ and extended current monitoring system in Jesuit church in Telc.

\section{Conclusion}

The indoor climate in Jesuit church in Telc is formed by natural hygrothermal response of historical church on outdoor climate since 1667 . This natural indoor climate with small hygrothermal fluctuation is assessments by Historical climate method as stable indoor climate. The low frequency of natural indoor climate in Target range is caused by low indoor air temperature in Jesuit church. This low indoor air temperature is formed by natural hygrothermal response of historical church on outdoor climate. The change of natural indoor climate is not supported with respect to good condition of historical furniture and valuable artefacts without failures. This good condition of historical furniture and valuable artefacts is caused probably by stable natural indoor climate with insignificant frequency of Frost risk, Microbiology risk and Dryness effect.

Finally, preventive conservation method of Historical climate is preferred in case study of Jesuit church of Holy Name Jesus in Telc. 


\section{Acknowledgment}

This conference contribution is created thanks to Memorandum on scientific cooperation concluded among Brno University of Technology, Faculty of Civil Engineering with National Heritage Institute, Regional Branch in Telc and Fraunhofer Institute for Building Physics, Holzkirchen Branch.

This conference contribution is supported by project LO1408 »AdMAS UP - Advanced Materials, Structures and Technologies « and internal research project at Brno University of Technology FAST-J-18-5574.

\section{References}

1. Aghemo C., Filippi M., Prato E.; Condizioni ambientali per la conservazione dei beni di interesse storico e artistico, Ricerca bibliografica comparat; Comitato Giorgio Rota 1997

2. D’Agostino V. Condizioni microclimatiche $e d i$ qualità dell'aria negli ambienti museali; Dissertation Thesis; Napoli 2006 [http://www.fedoa.unina.it/1071/]

3. M.BB.CC. 2001; Atto di indirizzo sui criteri tecnico-scientifici e sugli standard di funzionamento e sviluppo dei musei D.M. 10.5.2001; Supplemento ordinario alla G.U. n.244 dal Ministero per i Beni e le Attività Culturali, Ascoli Piceno 2011

4. Italian Standard UNI 10829:1999; Works of art of historical importance - Ambient conditions or the conservation - Measurement and analysis; UNI - Ente Nazionale Italiano di Unificazione, Milan 1999

5. IIC; The International Institute for Conservation of Historic and Artistic Works; United Kingdom Institute for Conservation; Taylor \& Francis Ltd.; London 1952 2011 (read in [1])

6. Musées de France; National France Système NOR MCCX0000178L; Paris 2002 (read in [1]).

7. Museo a Roma; AA. VV Atti del convegno AICARR Tecnologie impiantistiche per $i$ musei; Roma 2005 (read in [1])

8. Thomson G. The Museum Environment; $2^{\text {nd }}$ Edition (Butterworth-Heinemann Series in Conservation and Museology); ISBN: 978-0750620413; London 1986

9. European Standard CEN/TC 346 - Conservation of Cultural Heritage EN 15757:2010; Conservation of Cultural Property - Specifications for temperature and relative humidity to limit climate - induced mechanical damage in organic hygroscopic materials; European Committee for Standardisation, Brussels 2010

10. Caratelli A., Siani M. A., Casale R. G., Paravicini A., Fiore H. K., Camuffo D.; Stucco panels of Room VI in the Galleria Borghese (Rome): Physical-chemical analysis and microclimate characterization; Energy and Buildings 61 (2013) 133-139; ISSN: 0378-7788

11. Silva H. E., Henriques F. M.; Preventive conservation of historic buildings in temperate climates. The importance of a risk-based analysis on the decision- making process; Energy and Buildings 107 (2015) 26 36; ISSN: 0378-7788

12. Bertolin C., Camuffo D., Bighignoli I.; Past reconstruction and future forecast of domains of indoor relative humidity fluctuations calculated according to EN 15757:2010; Energy and Buildings 102 (2015) 197206; ISSN: 0378-7788

13. Slavata F. V. Historical document in archive E30 Society of Jesuit in Telc; sign 12/1 from 28 $8^{\text {th }}$ June 1662 deposited in the Moravian Provincial Archive in Brno.

14. Historical document in archive E30 Society of Jesuit in Telc; sign 25/4 deposited in the Moravian Provincial Archive in Brno.

15. Historical document in archive E33 Society of Jesuit in Znojmo; deposited in the Moravian Provincial Archive in Brno.

16. Historical document in archive 13558 in folder 139; deposited in Österreichische Nationalbibliothek Wien

17. Hnilica O., Zářecká K. Jesuit Church of Holy Name Jesus in Telc; building historical research; Telc 2018 deposited in National Institute of Heritage in Telc.

18. Ibidem in the book Cavarocchi F. Arte e artisti della Valle Intelvi: Con note Storico-Geografiche; 262 pages; S. Colombano al Lambro 1992

19. Google Inc., Street view of Telc in Czech Republic; [online: https://www.google.com/maps/@499.1850577,15 $.4518413,3 \mathrm{a}, 37.5 \mathrm{y}, 251.52 \mathrm{~h}, 93.4 \mathrm{t} / \mathrm{data}=! 3 \mathrm{~m} 6 ! 1 \mathrm{e} 1 ! 3 \mathrm{~m} 4 ! 1 \mathrm{~s}$ 4rxk MnWeHCdR7dSv6VJ6Q!2e0!7i13312!8i6656]

20. Google Inc., Street view of Val. d'Intelvi in the Italy; [online: https://www.google.cz/maps/@445.9573667,9.08 86642,3a,75y,93.01h,92.21t/data=!3m6!1e1!3m4!1sG53 F4vqVVZnAV2RuUfOFng!2e0!7i13312!8i6656]

21. Klíma I., Visual 3D model of Jesuit church in Telc; result of project NAKI II, DG16P02M043, Telc 2017

22. ASHRAE Handbook; Museums, galleries, archives and libraries; USA Society of Heating, Refrigerating and Air-Conditioning Engineers, Atlanta 2011

23. Balocco C., Petrone G., Maggi O., Pasquariello G., Albertini R., Pasquarella C.; Indoor microclimatic study for Cultural Heritage protection and preventive conservation in the Palatina Library; Journal of Cultural Heritage 22 (2016) 956-967; ISSN: 1296-2074

24. Bertolin C., Camuffo D., Bighignoli I.; Past reconstruction and future forecast of domains of indoor relative humidity fluctuations calculated according to EN 15757:2010; Energy and Buildings 102 (2015) 197206; ISSN: 0378-7788

25. Napp M., Kalamees T., Tark T., Arumägi E.; Integrated design of museum's indoor climate in medieval Episcopal Castle of Haapsalu; Energy Procedia 96 (2016) 592-600; ISSN: 1876-6102

26. Camuffo D., Pagan E., Rissanen S., Bratasz Ł., Kozłowski R., Camuffo M., Valle A.; An advanced church heating system favourable to artworks: 
A contribution to European standardisation; Journal of Cultural Heritage 11 (2010) 205-219; ISSN: 1296-2074;

27. Camuffo D., Pagan E., Bernardi A., Becherini F.; The impact of heating, lighting and people in re-using historical buildings: a case study; Journal of Cultural Heritage 5 (2004) 409-416; ISSN: 1296-2074

28. Bonacina C., Baggio P., Cappelletti F., Romagnoni P., Stevan G. A.; The Scrovegni Chapel: The results of over 20 years of indoor climate monitoring; Energy and Buildings 95 (2015) 144-152; ISSN: 0378-7788

29. Cardinale N., Ruggiero F.; A case study on the environmental measures techniques for the conservation in the vernacular settlements in Southern Italy; Building and Environment 37 (2002) 405-414; ISSN: 0360-1323

30. Camuffo D., Bertolin C. From Historical Climate to Comfortable Climate in Historic Buildings; Post-print from the Conference Energy Efficiency in Historic Buildings; ISBN: 978-91-86343-11-8; February 9-11; Visby 2011; [online: http://ictt.by/Docs/2012/2012-0525 01/\%D0\%A3\%D1\%81\%D0\%BF\%D0\%B5\%D0\%B D\%D1\%81\%D0\%BA\%D0\%B8\%D0\%B9 \%D0\%BF\% D1\%80\%D0\%BE\%D0\%B5\%D0\%BA\%D1\%82 COOL \%20Bricks/Energy_Efficiency in_Historic_Buildings.pd f] 